\title{
Uveal Melanoma Pathologic TNM Finding v8
}

National Cancer Institute

\section{Source}

National Cancer Institute. Uveal Melanoma Pathologic TNM Finding v8. NCI Thesaurus. Code C140611.

A pathologic finding about one or more characteristics of uveal melanoma, following the rules of the TNM AJCC v8 classification system. 